\title{
PENINGKATAN KUALITAS SUMBER DAYA MANUSIA PEGAWAI POSYANTEK SERPONG UTARA MELALUI PENDIDIKAN MENJADI SDM YANG UNGGUL DAN MAJU DALAM MENYONGSONG ERA INDUSTRI 4.0
}

\author{
M. Anton Nurhidayat, Riski Dwi Nugroho, H. Asep Sulaeman,Selvy Dwi Widiyanti, Anisa \\ Nurdiana \\ Dosen Ekonomi Fakultas Ekonomi Universitas Pamulang

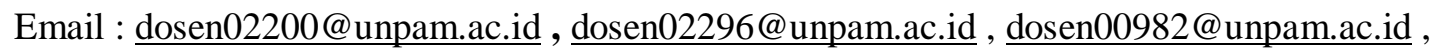 \\ dosen01007@unpam.ac.id, dosen02468@unpam.ac.id
}

\begin{abstract}
ABSTRAK
Salah satu dari tujuan Tridharma Perguruan Tinggi selain Pendidikan dan Penelitian adalah Pengabdian Kepada Masyarakat (PKM).Hal ini diatur dalam Pasal 20 dan 24 Undang-Undang. No. 20 Tahun 2003 tentang Sistem Pendidikan Nasional yang menyatakan bahwa adanya otonomi oleh Perguruan Tinggi, Penelitian Ilmiah dan Pengabdian Kepada Masyarakat. Sebagai pertanggungjawaban kami, maka dalam melaksanakan tugas tersebut telah kami susun laporan kegiatan pengabdian kepada masyarakat.

Era globalisasi membuka mata kita untuk melihat ke masa depan yang penuh dengan tantangan dan persaingan. Pengelolaan SDM dapat dilakukan misalnya dengan cara: (1)mengidentifikasi skill dan kualitas SDM yang serasi dengan tuntutan lingkungan,(2) memilih SDM yang memiliki kinerja tinggi dan potensial, (3)berusaha memenuhi kebutuhan organisasi dan individu, (4) menilai kinerja dan keahlian SDM, (5) memberi kompensasi yang memadai kepada tenaga yang terampil dan memiliki keahlian, (6) membangun lingkungan kerja yang baik, (8) meningkatkan motivasi untuk perbaikan kinerja

Pengembangan SDM pada intinya diarahkan dalam rangka meningkatkan kualitasnya, yang pada gilirannya akan dapat meningkatkan produktivitas. Hasil berbagai studi menunjukkan, bahwa kualitas SDM merupakan faktor penentu produktivitas, baik secara makro maupun mikro.Dalam pelaksanaan kami ingin mengembangkan Pendidikan pegawai Posyantek Serpong Utara agar dalam pelayanannya dapat diterima oleh masyarakat dengan memberikan bimbingan, pelatihan, pendampingan yang akhirnya hasil yang diciptakan menjadi tepat guna dan dapat bersaing pada industri 4.0. Oleh karena itu pengelolaan sumber daya manusia yang ada pegawai Posyantek diperlukan peningkatan kompetensi agar pemanfaatan Teknologi Tepat Guna (TTG) dapat dipahami dengan baik dan pengetahuan akan persaingan di industri 4.0 dapat dijawab dengan efektif dan efisien.
\end{abstract}

Kata Kunci: Pengembangan sumber daya manusia, Era globalisasi,Pendidikan dan Teknologi Tepat Guna

ABSTRACT
One of the goals of Higher Education Tridharma besides Education and Research is Community
Service (PKM). This is regulated in Articles 20 and 24 of the Law. No. 20 of 2003 concerning the
National Education System which states that there is autonomy by Universities, Scientific Research 


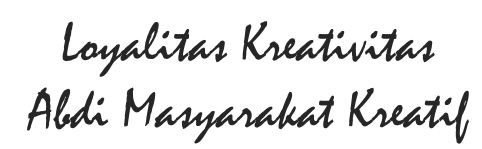

Loyalitas Kreativitas

Aldi Masyarakat Kreatil
Program Studi Ekonomi Manajemen Universitas Pamulang

Jurnal LOKABMAS Kreatif Vol. 01, No. 01, Hal. 8-14

Email:jurnalkreatif.manajemen@gmail.com

and Community Service. As our responsibility, in carrying out these tasks we have prepared reports on community service activities.

The era of globalization opens our eyes to see a future full of challenges and competition. HR management can be done for example by: (1) identifying HR skills and qualities that are in harmony with environmental demands, (2) selecting high-performance and potential human resources, (3) trying to meet the needs of organizations and individuals, (4) assessing performance and HR expertise, (5) provide adequate compensation to skilled and skilled personnel, (6) building a good work environment, (8) increasing motivation for performance improvement

HR development is basically directed to improve its quality, which in turn will increase productivity. The results of various studies show that the quality of human resources is a determinant of productivity, both macro and micro. In the implementation we want to develop the Education of North Serpong Posyantek employees so that in their services can be accepted by the community by providing guidance, training, assistance that ultimately the results created are appropriate and can compete in industry 4.0. Therefore, the management of existing human resources at Posyantek employees is needed to increase competence so that the utilization of Appropriate Technology (TTG) can be understood properly and knowledge of competition in industry 4.0 can be answered effectively and efficiently.

\section{Keywords: Human resource development, Globalization era, Education and Appropriate Technology}

\section{PENDAHULUAN}

\subsection{Analisis Situasi Permasalahan}

Dewasa ini sistem teknologi tepat guna sangat berperan dalam kehidupan manusia saat ini, dimana pemanfaatan sumber-sumber daya yang ada dapat dikelola dengan baik dan efisien.Sehingga masyarakat dapat mengidentifikasi sedini mungkin masalah-masalah yang dihadapi dalam kehidupan sehari-hari, baik itu pemerintah, pengusahan, perguruan tinggi, petani, home industri dan lain sebagainya.Sehingga pada tahun 1998 pemerintah mendirikan Pos Pelayanan Teknologi Pedesaan (Posyantekdes) melalui menteri dalam negeri. Diaman pada saat itu Posyantekdes menintruksikan para gubenur, bupati/wali kota dan camat di seluruh Indonesia utuk mensosialisasikan dan mengoprasionalisasikan Posyantekdes dengan cara memberikan penyuluhan, pengarahan, bimbingan dan pengawasan terhadap pelaksanaan Posyantekdes.

2. Salah satu isu penting dalam penyelenggaraaan pendidikan di Indonesia saat ini adalah peningkatan mutu pendidikan, namun yang terjadi justru kemerosotan mutu pendidikan dasar, menengah, maupun tingkat pendidikan tinggi. Hal ini berlangsung akibat penyelenggaraan pendidikan yang lebih menitikberatkan pada aspek kuantitas dan kurang dibarengi dengan aspek kualitasnya, dilihat dari peringkat negara,kualitaspendidikan Indonesia ber ada di urutan ke-160 dunia dan urutan ke-16 di Asia. Bahkan secara ratarata, Indonesia masih berada di bawah Vietnam

\subsection{Rumusan Masalah}

Pada sisi peningkatan kualitas SDM, pembangunan diarahkan untuk menjadikan rakyat negeri ini kreatif, menguasai serta mampu mengembangkan ilmu pengetahuan, teknologi dan seni (IPTEKS), dan memilikimoralitas.Kreatifitasdiperluk an untuk bisa bertahan hidup dan tidak rentan dalam menghadapi berbagai kesulitan. Dengan kreatifitas, seseorang menjadi dinamis dan bisa menemukan jalan keluar yang positif 


\section{Loyalitas Kreativitas \\ Aldi Masyarakat Kreatif}

P-ISSN 2722-2101, E-ISSN 2722-4201

Program Studi Ekonomi Manajemen Universitas

Pamulang

Jurnal LOKABMAS Kreatif Vol. 01, No. 01, Hal. 8-

14

Email:jurnalkreatif.manajemen@gmail.com

ketika menghadapi kesulitan atau masalah.

Dengan mempertimbangkan latar belakang yang sudah diutarakan diatas kami berinisiatif untuk membentuk pengabdian kepada masyarakat yang sudah bekerjasama dengan Kecamatan Serpong Utara Tangerang Selatan melalui peningkatan Pendidikan agar pemanfaatan Posyantek tersebut dapat diterima oleh masyarakat dengan memberikan bimbingan, pelatihan, pendampingan yang akhirnya hasil yang diciptakan tepat guna dan dapat bersaing pada industri 4.0. Oleh karena itu pengelolaan sumber daya manusia yang ada di Posyantek diperlukan peningkatan kompetensi agar pemanfaatan teknologi tepat guna dapat dipahami dengan baik dan pengetahuan akan persaingan di industri 4.0 dapat dijawab dengan efektif dan efisien.

\subsection{Tujuan Pengabdian kepada} Masyarakat

1) Memberikan pengetahuan mengenai pentingnya peningkatan pendidikan

2) Memberikan pengetahuan mengenai TTG (Teknologi Tepat Guna)

3) Melaksanakan rencana kerja sesuai dengan bidang dan kompetensinya

4) Memberikan pendampingan dan bimbingan teknis kepada pemanfaatan TTG

5) Memberikan pengenalan Revolusi Industri 4.0, permasalahan dan solusi mengatasinya

\subsection{Manfaat Pengabdian kepada Masyarakat}

Semua kegiatan yang dilakukan dari pengabdian kepada masyarakat ini diharapkan akan memberikan manfaat baik secara internal (akademisi) dan eksternal (masyarakat umum). Dalam pengabdian kepada masyarakat yang dilakukan oleh dosen serta mahasiswa Fakultas Ekonomi program studi Manajemen Universitas Pamulang diharapkan mampu memberikan solusi dan pembekalan teknis manajemen dalam pengembangan sumber daya manusia agar masyakat mampu mengembangkan kompetensinya agar mampu bersaing dalam sebuah organisasi khususnya pegawai posyantek dalam pentingnya peningkatan pendidikan dalampemanfaatan teknologi tepat gunayang ada di wilayah Kecamatan Serpong Utara Tangerang Selatan.

\section{TINJAUAN PUSTAKA}

\subsection{Posyantek}

\subsubsection{Pengertian Posyantek}

2. Posyantek adalah Pos Pelayanan Teknologi yang tersebar di setiap kecamatan di Indonesia. Hal utama dari Posyantek adalah bagaimana meningkatkan kesejahteraan dan kemandirian masyarakat di wilayah kecamatan melalui pemanfaatan teknologi tepat guna (TTG).

3. Dalam menempuhnya Posyantek memiliki berbagai kegiatan yang antara lain terkait dengan memberikan layanan teknis, informasi, dan promosi tentang berbagai jenis TTG kepada masyarakat, meningkatkan kualitas dan kuantitas berbagai jenis produk yang dihasilkan Usaha Kecil dan Menengah di Masyarakat (UKM) serta menjadi jembatan masyarakat sebagai pengguna TTG dalam rangka pemanfaatan TTG.

\subsubsection{Tujuan Posyantek}

Tujuan pembentukan dan pengembangan Posyantek adalah sebagai berikut:

1) Menjembatani masyarakat pemanfaat/pengguna Teknologi Tepat Guna (TTG) dengan sumber TTG;

2) Memberikan kemudahan kepada masyarakat dalam memperoleh pelayanan teknis, pelayanan informasi dan promosi berbagai jenis TTG kepada masyarakat; dan 


\section{Loyalitas Kreativitas \\ Aldi Masyarakat Kreatif}

P-ISSN 2722-2101, E-ISSN 2722-4201

Program Studi Ekonomi Manajemen Universitas

Pamulang

Jurnal LOKABMAS Kreatif Vol. 01, No. 01, Hal. 8-

14

Email:jurnalkreatif.manajemen@gmail.com

3) Meningkatkan kerjasama dan koordinasi antar pemangku kepentingan dalam rangka pemanfaatan TTG.

\subsubsection{Fungsi Posyantek}

Posyantek itu sendiri memiliki 4 (empat) fungsi, yaitu:
1) Chanelling, artinya menghubungkan pembuat mesin dan konsumen (masyarakat).

2) Perpustakaan, artinya menyediakan buku-buku dan cara-cara mengenai Teknologi Tepat Guna.

3) Informasi, artinya memberikan informasi berkaitan dengan perkembangan TTG kepada masyarakat.

4) Bengkel, artinya menerima pemesanan dan memperbaiki alat-alat TTG.

Keberadaan Posyantek dinilai sangat penting dalam proses penerapan TTG dalam masyarakat. Setiap Kabupaten harus memiliki Posyantek di tingkat Kecamatannya, karena hal ini telah diintruksikan menurut peraturan perundangundangan.

\section{MATERI DAN METODE \\ PELAKSANAAN}

\subsection{Kerangka Pemecahan Masalah}

Kerangka pemecahan masalah merupakan serangkaian prosedur dan langkah-langkah dalam kegiatan pengabdian kepada masyarakat (PKM) yang bertujuan untuk mendapatkan tahapan yang terstruktur secara sistematis, sehingga (PKM) dapat dilakukan dengan efektif dan efisien.

\footnotetext{
Output yang ada dalam PKM, meliputi pengklasifikasian atribut Posyantek sebagai mitra masyarakat dalam mengembangkan pendidikan dalam pemanfaatan teknologi tepat guna (TTG) agar setiap program dan pelaksanaan dapat bermanfaat untuk
}

masyarakat sekitar.Kegiatan pelaksanaan biasa dimulai dari diskusi, kelas, seminar (workshop), pelatihan dan pendampingan sehingga tujuan akhir dari Posyantek yang tepat guna dapat berjalan secara efektif dan efisien dalam menuju persaingan industry global saat ini (revolusi industry 4.0).Uraian kerangka pemecahan masalah, meliputi:

1) Studi Lapangan

Studi lapangan meliputi observasi, pengumpulan data yang berhubungan dengan materi PKM, serta wawancara dengan pihak-pihak yang terkait yang dapat mendukung kegiatan PKM.

2) Studi Pustaka

Studi pustaka sebagai dasar untuk memperoleh referensi yang baik agar laporan PKM dapat dipertanggungjawabkan secara ilmiah.Studi pustaka berisikan teori yang berhubungan dengan objekobjek PKM.

\subsection{Realisasi Pemecahan Masalah}

Langkah yang dilaksanakan dalam kegiatan ini merupakan langkah awal dari Pengabdian Kepada Masyarakat dimulai dari observasi langsung ke lokasi Posyantek yang berada di Kecamatan Serpong Utara, dan mencari informasi yang dibutuhkan pada saat pelaksanaan PKM.Langkah selanjutnya menetapkan tujuan PKM, kemudian mengidentifikasikan permasyalahan tersebut dalam bentuk proposal PKM.Langkah terakhir adalah melakukan kegiatan PKM, serta membuat hasil kegiatan PKM.

\subsection{Khalayak Sasaran}

Sasaran yang ingin di capai melalui program peningkatan pendidikan dalam pemanfaatan teknologi tepat guna (TTG) adalah agar teknologi yang digunakan sesuai dengan kebutuhan masyarakat, dapat menjawab permasalahan masyarakat, tidak merusak lingkungan dan dapat 


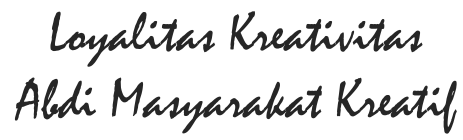

P-ISSN 2722-2101, E-ISSN 2722-4201

Program Studi Ekonomi Manajemen Universitas

Pamulang

Jurnal LOKABMAS Kreatif Vol. 01, No. 01, Hal. 8-
14

Email:jurnalkreatif.manajemen@gmail.com

dimanfaatkan oleh masyarakat secara mudah serta menghasilkan nilai tambah dari aspek ekonomi dan aspek lingkungannya. Sehingga dengan bersenergi dengan Posyantek Kecamatan Serpong Utaradiharapkan masyarakat baik perseorangan, lembaga pemerintah/swasta dapat menghasilkan sebuah produk yang ramah lingkungan dan tepat guna yang dapat dimanfaatkan oleh warga Kecamatan Serpong Utara Tangerang Selatan.

\subsection{Tempat dan Waktu}

Rencana pelaksanaan kegiatan adalah sebagai berikut.Tempat: Aula Kantor Kecamatan Serpong Utara Tangerang Selatan

Waktu Pelaksanaan Kegiatan: 2527Oktober 2019

\subsection{Metode Kegiatan}

Persoalan ketenagakerjaan selalu mendapat perhatian yang serius dari berbagai kalangan, baik pemerintah, swasta maupun dari masyarakat.Kompleksitas permasalahan ketenagakerjaan ini dapat dipandang sebagai suatu upaya masingmasing individu untuk memperoleh dan mempertahankan hak-hak kehidupan yang melekat pada manusia agar memenuhi kebutuhan demi kelangsungan hidup.

Jalur pendidikan merupakan tulang punggung pengembangan SDM yang dimulai dari tingkat dasar sampai perguruan tinggi.Sementara itu, jalur pelatihan dan pengembangan karir di tempat kerja merupakan jalur suplemen dan komplemen terhadap pendidikan.

Metode kegiatan yang digunakan adalah melalui kunjungan langsung ke Kecamatan Serpong Tangerang Selatan khususnya tempat Pos Pelayanan Teknologi Terpadu (Posyantek), dengan memberikan seminar, pelatihan dan pendampingan terhadap pegawai Posyantek yang ada dilingkungan Kecamatan Serpong Utara Tangerang Selatan.

\section{HASIL DAN PEMBAHASAN}

Teknologi Tepat Guna yang biasa disebut TTG adalah teknologi yang sesuai dengan kebutuhan masyarakat, dapat menjawab permasalahan masyarakat, tidak merusak lingkungan, dapat dimanfaatkan dan dipelihara oleh masyarakat secara mudah, serta menghasilkan nilai tambah dari aspek ekonomi dan aspek lingkungan..

Tantangan zaman kita tidak hanya pada persaingan dan ekspansi ekonomi global, namun juga pada fenomena revolusi industry 4.0. Sejatinya, ketika hal ini tidak diberikan perhatian yang serius dan lebih, maka bonus demografi yang akan dimiliki bangsa Indonesia menjadi tidak ada artinya. Revolusi indutri 4.0 akan berpotensi besar mengubah 'tatanan' kehidupan manusia, dimana dampaknya sedikit demi sedikit sudah terlihat di era saat ini. Perubahan tatanan kehidupan itu jelas akanmengubah seluruh peta kehidupan sosial dan ekonomi kita, dimana salah satunya berdampak perubahan lapangan-lapangan pekerjaan, yang masih bersifat konvensional menuju penggunaan teknologi digital.

\section{KESIMPULAN DAN SARAN}

\subsection{Kesimpulan}

Dalam pelaksanaan kami ingin mengembangkan Sumber Daya Manusia Melalui Peningkatan Pendidikan agar pemanfaatan TTG ini dapat diterima oleh masyarakat dengan memberikan bimbingan, pelatihan, pendampingan yang akhirnya hasil yang diciptakan menjadi tepat guna dan dapat bersaing pada industri 4.0. Oleh karena itu pengelolaan sumber daya manusia yang ada pegawai Posyantek diperlukan peningkatan kompetensi agar pemanfaatan Teknologi Tepat Guna (TTG) dapat dipahami dengan baik dan pengetahuan akan persaingan di industri 4.0 dapat dijawab dengan efektif dan efisien.

Dalam rangka meningkatkan sistem usaha pembangunan masyarakat supaya lebih produktif dan efisien, diperlukan teknologi. Pengenalan 


\section{Loyalitas Kreativitas \\ Aldi Masyarakat Kreatif}

P-ISSN 2722-2101, E-ISSN 2722-4201

Program Studi Ekonomi Manajemen Universitas

Pamulang

Jurnal LOKABMAS Kreatif Vol. 01, No. 01, Hal. 8-
14

Email:jurnalkreatif.manajemen@gmail.com

teknologi yang telah berkembang di dalam masyarakat adalah teknologi yang telah dikembangkan secara tradisional, atau yang dikenal dengan "teknologi tepat guna" atau teknologi sederhana dan proses pengenalannya banyak ditentukan oleh keadaan lingkungan dan mata pencaharian pokok masyarakat tertentu.

\subsection{Saran}

Guna tercapai tujuan dari Posyantek dalam menyelenggarakan teknologi tepat guna secara efektif dan efisien dalam menyongsong era industry 4.0 ada beberapa saran yang perlu diperbaiki, yakni:

\section{1) Komunikasi}

Komunikasi disini sangatlah penting karena keberhasilan dalam berkomunikasi antara penyelenggara Posyantek dengan masyarakat, maka akan memudahkan program-program posyantek dapat berjalan dengan baik.

2) Sumber daya manusia

Menambah jumlah pegawai pelaksana program TTG dan meningkatkan pengetahuan agar mampu menjangkau pelaksanaan program TTG dan pelayanannya dapat diterima masyarakat sampai wilayah terpencil.

3) Struktur organisasi

Perlunya struktur organisasi yang baik agar alur kegiatan TTG dapat tepat sasaran agar Standar Operasinal Pekerjaan (SOP) dapat dijadikan acuan dalam bekerja.

\section{DAFTAR PUSTAKA}

Bahreisy, Hussein. 1980. Himpunan Hadist Pilihan: Hadist Shahih Bukhari. Surabaya: Al Ikhlas.

Bramley, Peter. 1991. Evaluating Training Effectiveness. London. The McGraw-Hill Training Series.

Depdiknas.2001. Kebijaksanaan di
Bidang Pendidikan Dasar. Jakarta:

Dirjen Dikdasmen.

Djojonegoro, Wardiman. 1995.

Peningkatan Kualitas Sumber Daya

Manusia untuk Pembangunan. Jakarta:

Depdikbud.

Engkoswara. 2001. Paradigma

Manajemen Pendidikan Menyongsong

Otonomi Daerah. Bandung:Yayasan

Amal Keluarga.

Fattah, Nanang. 2000. Ekonomi dan Pembiayaan Pendidikan. Bandung:

Remaja Rosdakarya.

Garis-garis Besar Haluan Negara (GBHN). 1998.

Kartadinata, Sunaryo. 1997.

Pendidikan dan Pengembangan SDM

Bermutu Memasuki Abad XXI.

Purwokerto: Makalah Konvensi.

Sanusi, Achmad. 1998. Pendidikan

Alternatif. Bandung:Program

Pascasarjana dan PT Grafindo Media

Pratama.

Siagian, Sondang P. 1998. Manajemen Sumber Daya Manusia. Jakarta:Bumi Aksara.

Sutermeister, Robert A. 1976. People and Productivity. Tokyo:Mc Graw-Hill Books Company.

Mokoginta, Urip A., Sjabadhyni, Bertina, Graito, Indarwahyanti, dan Wutun, Rufus Patty. 2007. Dinamika Perubahan Organisasi Dari Sistem keIndividu.Jakarta : Bagian Psikologi Industri dan Organisasi Fakultas Psikologi Universitas Indonesia

Efendi Hariandja, Marihot Tua, Manajemen Sumber Daya Manusia 


\section{Loyalitas Kreativitas \\ Aldi Masyarakat Kreatif}

P-ISSN 2722-2101, E-ISSN 2722-4201

Program Studi Ekonomi Manajemen Universitas

Pamulang

Jurnal LOKABMAS Kreatif Vol. 01, No. 01, Hal. 8-

14

Email:jurnalkreatif.manajemen@gmail.com

Pengadaan, Pengembangan,

Pengkompensasian dan

PeningkatanProduktivitas Pegawai, PT. Grasindo, Jakarta, 2007

Suharyanto, Hadrianus, dan Agus Herianto Hadno, Manajemen Sumber DayaManusia, Media Wacana, Yogyakarta, 2005

Hasibuan, Malayu, Manajemen Sumber Daya Manusia, edisi revisi, Penerbit, Bumi Aksara, Jakarta, 2005

Hariandja, M.T.E . (2002). Manajemen SDM: Pengadaan, Pengembangan,

Pengkompensasian dan Peningkatan Produktivitas Pegawai. PT. Gramedia Widiasarana Indonesia Jakarta

Pasaribu, V. L. D., Agrasadya, A., Shabrina, N., \& Krisnaldy, K. (2020). MENJADI ENTERPRENEUR MUDA YANG MEMILIKI JIWA LEADERSHIP UNTUK MENGHADAPI MASA DEPAN. $A b d i$

Laksana, 1(1)

Pasaribu, V. L. D., Elburdah, R. P., Sudarso, E., \& Fauziah, G. (2020). PENGGUNAAN MANAJEMEN WAKTU TERHADAP PENINGKATAN PRESTASI BELAJAR DI SMP ARAISIYAH. Jurnal ABDIMAS, 1(1)

Pasaribu, V. L. D., Susanti, F., \& Hartuti, E. T. K. (2019). MEMOTIVASI SISWA DAN SISWI SMK LETRIS INDONESIA DI DALAM MENENTUKAN PILIHAN UNTUK MELANJUTKAN PENDIDIKAN ATAU BEKERJA SETELAH LULUS SEKOLAH. Jurnal Pengabdian Dharma Laksana, 1(2), 161-172.

\section{DOKUMENTASIFOTO KEGIATAN}
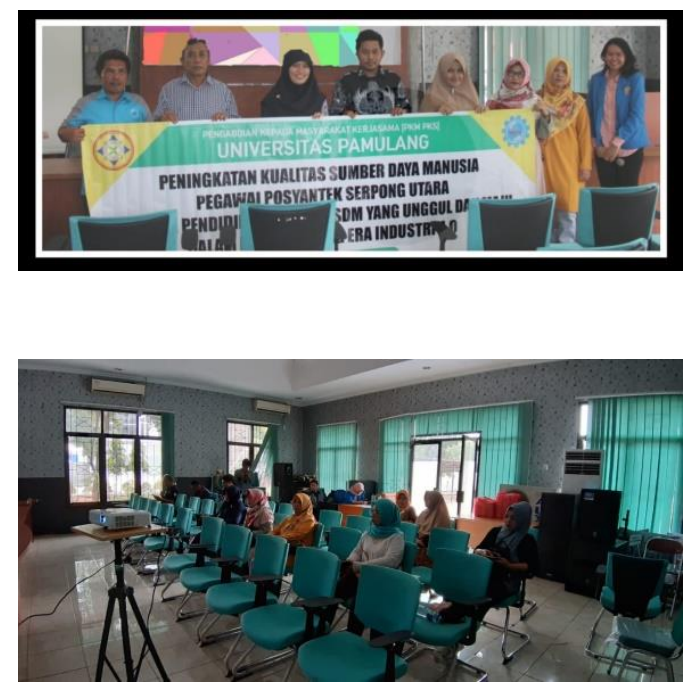